\title{
AWARENESS OF RISKS, HAZARDS AND PREVENTIONS IN AUTOPSY PRACTICE: A REVIEW
}

Kusa Kumar Shaha ${ }^{1}$, Ambika Prasad Patra², Siddhartha Das ${ }^{3}$, Sanjay Sukumar ${ }^{4}$, Manoj Kumar Mohanty 5 .

1. Assistant Professor, Department of Forensic medicine \& Toxicology, Jawaharlal Institute of Post-graduate Medical Education \& Research Puducherry,

2. Senior Resident, Department of Forensic medicine \& Toxicology, Jawaharlal Institute of Post-graduate Medical Education \& Research Puducherry,

3. Assistant Professor, Department of Forensic medicine \& Toxicology, Jawaharlal Institute of Post-graduate Medical Education \& Research Puducherry,

4. Assistant Professor, Department of Forensic medicine \& Toxicology, Jawaharlal Institute of Post-graduate Medical Education \& Research Puducherry,

5. Additional Professor, Department of Forensic medicine \& Toxicology, Jawaharlal Institute of Post-graduate Medical Education \& Research Puducherry,

\section{CORRESPONDING AUTHOR:}

Dr. Kusa Kumar Shaha,

Department of Forensic medicine \& Toxicology,

Jawaharlal Institute of Post-graduate Medical Education \& Research,

(Govt. of India), Puducherry, India.

Email-drkusashaha@yahoo.com

ABSTRACT: The present paper highlights the steps followed to prevent the risks and hazards encountered at mortuary. Autopsy surgeons or Forensic pathologists and the personnel who assist in conducting the autopsy are liable to encounter a number of accidents and potential biohazards; who are at a continuous risk of acquiring various kinds of viral, bacterial infections from contagious body fluids, soft tissues of the dead and skin injuries. The prevailing practice of autopsy in major parts of world including India is empirical and crude and is due to ignorance, administrative apathy, under funding and lack of implementation of effective skill oriented programs on safe autopsy practice and for development of an optimally equipped mortuary. Safety in morgues is not only relevant to the team performing the autopsy, but also has adverse environmental effects e.g. contamination with radioactive and other contagious substances. By adhering to approved safety precautions and autopsy techniques, the risk of hazards at work place may be minimized. The present literature reviewed the risks related to the existing autopsy practice and discussed appropriate preventive, bio-safety measures to be taken. This paper highlights the preparation of safety guidelines for routine autopsy practice; which should be devised by forming appropriate committees which may include the practicing autopsy surgeons, mortuary personnel, the professionals from local infection control and occupational health and safety departments. The existing safety measures in a mortuary set-up should be evaluated and reconsidered after reviewing appropriate safety guidelines. Time to time organization of induction programs, workshops, continued medical education on safe autopsy practice will be a great help for the persons concerned. Nevertheless, the goal of such practice is to protect the concerned workers and the environment as well, from the potential risks associated with morgues.

KEYWORDS: autopsy, safety, forensic pathologist, autopsy-room, risk, hazards, potential, preventive measure 


\section{INTRODUCTION:}

In many parts of the world, autopsy retains its value for determining the cause of death, detecting clinically unknown lesions, as a quality assurance tool, and providing accurate information for death certification. ${ }^{[1]}$ Autopsy safety was not much concerned until early eighties, when the risk of contamination with HIV-AIDS appeared.[2]According to a study by Morris in 1946, majority of medical undergraduates who were attended mortuary for post-mortem demonstration classes became tuberculin positive. ${ }^{[3]}$ Nevertheless, autopsy surgeons or the forensic pathologists and other mortuary personnel are potentially exposed to the danger of unknown contagious and non-infectious threats associated with routine postmortem examination. And the chances are increased in multifold during mass casualties, or during autopsies on undiagnosed or misdiagnosed cases. ${ }^{[4,5,6,7,8,9]}$

Currently, in many developing countries majority of mortuaries are woefully out of date and far away from the modern safety norms. Very few nations are equipped with world class autopsy facilities like BSL (Bio-Safety Level) 3 or 4. And, this may be due to cost constraints; because, as such these units are expensive to build, operate and maintain appropriately. However, the drawback with this existing contingency facility is immobility; because, normally these are housed in permanent structures and cannot be moved to distant locations to deal with emergency autopsies. Most autopsy centres are located in the native building sharing the ventilation and drainage with other spaces in the building, and often are old fashioned without fulfilling the criteria for a recommended safety design. Nevertheless, it is the responsibility of the employers to provide an adequately equipped and safe morgue facility.[10,11,12]

During mass casualties like terrorist attacks, bomb blasts, public stampedes, massacre or riots, loads of bodies are brought to the morgue and often very crude, hasty methods of autopsy are followed with a priority to fulfil the statutory or administrative needs. Often, the medical examiners are called for the spot autopsy in cases of advanced decomposition or grossly mutilated bodies where transport of body to the morgue may cause significant loss of evidence. Such spot autopsies are carried out with very limited resources and in potentially risky environment. For all such problems, there is only one satisfactory solution i.e. portable morgue. However, in most of the developing countries the concept of 'portable morgue' is still in preconception stage. Although, in some parts of developed world palletized mortuary systems are available e.g. Disaster Mortuary Operational Response Team (DMORT) organized by the U.S. federal government; but, they have no capacity for biosafety stringency, or for microbiologic diagnosis.

Therefore, it is ideally recommended for a mobile containment autopsy facility that might be useful in providing autopsy support to the needy, remote areas.[13] The present day challenge is to meet the need for providing appropriate facilities for autopsies of contaminated bodies and to do so at a lesser cost and time. 


\section{REVIEW ARTICLE}

\section{DISCUSSION:}

1. Hazards/risks in mortuary and safety levels.

2. General considerations for the development of a modern, biosafety compliant mortuary.

3. Building concept of modern safe mortuary set-up.

HAZARDS/RISKS IN MORTUARY AND SAFETY LEVELS: Technically 'hazard' is the injuries inflicted during the autopsy procedure; while the 'risk' is the chances of acquiring communicable diseases or infections e.g. HBV (Hepatitis B virus), HIV (Human Immunodeficiency Virus) etc. ${ }^{[14]}$ Autopsy personnel have a ten-fold increased risk and relative risk, compared to the general population and is 100-200 times greater chances of encountering unknown threats while performing autopsies.[15]They might be routinely exposed to a wide variety of blood-borne and aerosolized pathogens such as HIV, Hepatitis B, C, G viruses, and non-A, non-B hepatitis viruses, tuberculosis, SARS (Severe Acute Respiratory Syndrome) virus etc. In general, infective material is introduced through accidental puncture wounds from needles or other sharp instruments, splashes into mucous membranes, inhalation, or the passage of the infective agent through breached skin or mucosa membrane.[16] Gram negative bacilli is considered as an indicator of bacterial load, found in maximum counts during bowel removal and washing of the intestines.[13]The recovery of gram negative bacilli from the hands of mortuary personnel after autopsy on removing the gloves is a clear evidence of skin contamination from cadaver.[13,17]It is prudent to consider all autopsies as a potential infective source. Many studies have confirmed that with the cessation of life, certain pathogenic bacteria are released, which if left unchecked, may prove hazardous to the personnel dealing with them..17,18] Moreover, after death, there is neither the reticulo-endothelial system (RES) nor the blood-brain barrier to restrict the translocation of micro-organisms and the pathogens within the dead body.[18]

It is not uncommon to find dead bodies of unknown background brought for the postmortem examination, and as such the burden of risks of infection from these bodies are also unknown. ${ }^{[19]}$ Often, there is social, ethical pressures which restrict the availability of information about the dead, especially death from AIDS (Acquired Immuno Deficiency Syndrome), drug abuse etc. And, this in turn burden up significantly risk of infection transmission to the mortuary workers.[19] In this context every dead body should be considered potentially infectious and dealt accordingly as per the recommended precautions, procedural techniques and knowing the principles of pre-exposure prophylaxis (PEP).[7,20]Six categories of potential risks to the forensic pathologists are encountered during the performance of autopsy; and these are mechanical injuries from fall, slippage over the floor etc, sharp cutting injuries, electrocution, exposure to toxic chemicals (e.g. formalin, cyanide, organophosphates etc), infection and radiation exposure from radionuclides used for radiotherapy and diagnosis.[17]The risk categories, activities leads to risks and preventive measures are listed in table 1, and table 2,table 3 respectively. The disinfectants used during Autopsy and their Effectiveness [19] listed in table 4. Babb et al (1989) recorded hand glove punctures during autopsy in 38\% among mortuary assistants and 12\% among forensic pathologist. About $67 \%$ of scalpel wounds are inflicted in the area consisting of the distal thumb, index and middle fingers of the non-dominant hand.[17]Nevertheless, inexperience, lack of awareness for the potential risks of autopsy examination is more frequent then the risks from the case itself.[21,12] 
GENERAL CONSIDERATIONS FOR THE DEVELOPMENT OF A MODERN, BIOSAFETY COMPLIANT MORTUARY:

The entire autopsy area and its contents are should be designated as a biohazard area and appropriate warning signs are to be labeled. It has been shown that vast majority of morgue accidents and hazards are due to human errors and ignorance. Therefore, safety awareness in the mortuary premises is an effective preventing step. ${ }^{[22]}$ There are certain Biosafety guidelines have been established for biomedical and microbiological laboratories by various authorities e.g. World Health Organization (WHO), Department of Health and Human Services (1999), U.S., National Institutes of Health, India etc.[21]Should the same principles be introduced to the morgue rooms too? Nolte et al (2001) opined that the biosafety principles that have been developed for clinical laboratories, biomedical research laboratories and animal facilities could be broadly applied to morgues too.[13]The cornerstone of any autopsy biosafety program, therefore, is the practice of standard infection control precautions.[23]

In the autopsy room there is no place for fear or ignorance. If multiple autopsies are to be performed sequentially, those with the greatest infective risk should be done first, before the staff becomes fatigued. All injuries are not preventable, but they should not be the result of carelessness, mistake or negligence. Competent, experienced, and professional approach results in decrease of the injury rate.[12]These risks can be substantially mitigated through proper assessment, personal protective equipment, appropriate autopsy procedures, and facilities design.[13] A retrospective study on the use of personal protective equipments (PPE) has demonstrated their effectiveness in significantly reducing the injuries.[24]The autopsies performed on bodies with contagious diseases requires a facility of effective decontamination. Hence, use of universal biosafety guidelines in the autopsy room e.g. adequate ventilation, air handling systems, controlled access etc can go a long way in preventing the occupational hazards.[25,26]

BUILDING CONCEPT OF MODERN SAFE MORTUARY SET-UP: This concept mixes up learning from sanitary engineering, chemical hygiene, odour control, architecture and safety. Nevertheless, it is the concept globally followed by industries and other fields of hazardous work environments.[26, 27] An ideally designed mortuary set-up should contain the following infrastructures:

a. BUILDING MANAGEMENT SYSTEMS (BMS): Contemplating a modern mortuary or any other such building development without BMS is likely to be a futile endeavour. Because, it has a pivotal role in maintaining the relevant aspects of each facility such as ventilation, sewage controls, safety, alarms and other security concerns. Before preparing to build a mortuary set-up, a consensus should be made by the appropriate authority or committee keeping international guidelines on background; and, than the bases for design and building improvement are outlined. 
b. ADEQUATE VENTILATION: Continuous fresh air circulation within the work spaceis mandatory in terms of removal of contaminants. Constitutive elements and sealing technologies for the duct work or pipe lines, which could be able to prevent damage by corrosives, vapor phases, condensates that may form within the system. Ample number of exhaust units should be provided to remove aerosols created during a infectious autopsies.

c. FLOORING: The floor should be designed to resist chemical adsorption. Because, routine chemicals used for viscera preservation, toxicological analysis, tissue fixing or other histopathology procedures may corrode or alter the floor. Cementitious or synthetic seamless laminated flooring is preferred.

d. FURNITURE: Chemicals, blood or other body fluid and water adsorption should be considered and furniture made up of wood or wood derivates are avoided. Door handles, hinges and locks should also be corrosion resistant. Stainless steel furniture and accessories are preferred.

e. SEWAGE DISPOSAL: The normal cleaning of the autopsy tables generate a high lipid content liquid waste. Hence, it possesses risk of clogging the piping and drains. It can be avoided by using chemical cleansers and thermal jacketing all the way down to the liquid waste treatment plant.

f. ODOUR CONTROL: A very sensitive aspect for the conception of forensics buildings is odor control. This will impact directly on the community perception and the environment. This can be avoided by using odor control technologies like activated carbon particles.

CONCLUSION: High prevalence of hazards and risks poses a great threat to autopsy workers. It is noteworthy that safety administration may be neglected until something goes wrong. The hazards present within a body are often unknown at the start of the necropsy and hazardous conditions cannot be anticipated too. Occupationally acquired infections occur either by sharps injury or by inhalation. It is therefore prudent to consider all the dead bodies to be potential carriers of infection and follow the universal precaution guidelines. The autopsies should be planned to avoid inordinate time pressures and fatigue. Training and safety policies like standard prophylactic procedures, sincere use of personal protective equipments should be made available to all staff and encouraged to use their own common sense and discipline for their protection. In majority of cases there is tremendous loss of evidence, introduction of artifacts till the body reaches morgue; and advancement of decomposition process. Therefore, adequate number of mobile-autopsy facilities should be recruited, especially to the underprivileged, remote areas or to a site where contagious or toxic death cases are confronted. Nevertheless, autopsy room workers should be educated on the issue of the employees compensation act, so that it will help the workers feel more secure as work without fear, results in best and most effective outcome, which in turn would help in providing efficiently the purpose of our "social and legal justice". 
TABLE I: Risks and Hazards in Mortuary

\begin{tabular}{|c|c|c|}
\hline $\begin{array}{l}\text { Risk } \\
\text { Category }\end{array}$ & Activity & Risks \\
\hline $\begin{array}{l}\text { hysical } \\
\text { Risks }\end{array}$ & $\begin{array}{l}\text { 1. Use of heavy equipment/loads } \\
\text { 2. Lifting and dragging bodies on a } \\
\text { slippery floor }\end{array}$ & $\begin{array}{l}\text { Accidental injuries } \\
\text { - Musculoskeletal injury - particularly back strain } \\
\text { - } \quad \text { Slipping and falling. }\end{array}$ \\
\hline $\begin{array}{l}\text { Sharp Force } \\
\text { Injury }\end{array}$ & $\begin{array}{l}\text { Mishandling of during autopsy } \\
\text { a. Scalpel / needle, fragmented Bullets with } \\
\text { jackets }{ }^{[28]} \\
\text { b. Pointed ends of fragmented long bones } \\
\text { c.Medical devices such as surgical staples }{ }^{[29]} \\
\text { d. Needle fragments in drug-addicts. }{ }^{[30]}\end{array}$ & $\begin{array}{l}\text { - } \quad \text { Cut or Puncture. } \\
\text { Distal thumb and index and middle fingers, are } \\
\text { the most frequent injuries sustained by } \\
\text { pathologists.[31] }\end{array}$ \\
\hline $\begin{array}{l}\text { Electrical } \\
\text { Injury }\end{array}$ & $\begin{array}{l}\text { 1. Electrical instruments (Saws) are } \\
\text { routinely handled with wet gloves } \\
\text { 2. Poorly maintained Electrical fittings } \\
\text { and connections. } \\
\text { 3. Often implanted cardioverter- } \\
\text { defibrillator in dead bodies.[32] }\end{array}$ & Shock and Electrocution \\
\hline $\begin{array}{l}\text { Chemical } \\
\text { Exposure }\end{array}$ & $\begin{array}{l}\text { 1. Formaldehyde } \\
\text { a. Use as a fixative to preserve tissues for } \\
\text { histo-pathological examination. } \\
\text { b. Handling formalin- fixed } \\
\text { organs/specimens that have not been } \\
\text { thoroughly washed. } \\
\text { 2. Working in poorly ventilated areas.[33] } \\
\text { 3. Exposure to highly poisonous aerosol, } \\
\text { gases or volatile substances e.g. Organo- } \\
\text { phosphates (Malathion, Parathion) } \\
\text { poisoning deaths, Hydrogen sulfide, } \\
\text { Cyanide poisoning, while opening } \\
\text { stomach/other body cavities. }\end{array}$ & $\begin{array}{l}\text { 1. Formaldehyde cause: } \\
\text { a. Irritant effects on mucous membranes of eyes, } \\
\text { respiratory tract and skin.[34] } \\
\text { b. Menstrual reproductive disorder, sexual } \\
\text { dysfunction. }{ }^{[35]} \\
\text { c. Long-term exposure to the substance has also } \\
\text { been associated with an increased risk for all } \\
\quad \text { cancers, particularly the cancer of lung.[36] } \\
\text { d. Long-term inhalation has carcinogenic effects. } \\
\text { 2. Loss of concentrations / irritability / diminished } \\
\text { efficiency. } \\
\text { 3. Toxic gas poisoning (Acute/Chronic effects). } \\
\text { However, chronic toxicity is more commonly seen. }{ }^{[37]}\end{array}$ \\
\hline $\begin{array}{l}\text { Radiation } \\
\text { Exposure }\end{array}$ & $\begin{array}{l}\text { 1. Implanted radioactive materials for cancer } \\
\text { treatment. } \\
\text { 2. X-ray exposure before and during an } \\
\text { autopsy taken routinely and frequently. }\end{array}$ & $\begin{array}{ll}\text { - } & \text { Potential risk for radiation injuries } \\
\text { - } & \text { Malformation and congenital anomaly in female } \\
& \text { pregnant mortuary workers. }\end{array}$ \\
\hline $\begin{array}{l}\text { Infectious } \\
\text { Disease }\end{array}$ & $\begin{array}{l}\text { - Splashing/ Close contact [38] } \\
\text { - Broken skin [39] } \\
\text { - Mucosal surfaces. } \\
\text { with blood, body fluidsand tissues of dead } \\
\text { body with infectious diseases, drug addicts etc }\end{array}$ & $\begin{array}{l}\text { 1. Aerosol: Mycobacterial agents.[3] } \\
\text { 2. Blood/body fluid: HIV, Hepatitis B, Hepatitis C } \\
\text { \&Parasitic infection. } \\
\text { 3. Intravenous drug abusers: pose the greatest risk of } \\
\text { transmitting viral, bacterial agents like } \\
\text { Staphylococcus, streptococcus and salmonella.[40] }\end{array}$ \\
\hline
\end{tabular}




\section{TABLE II: Preventive Guidelines at Mortuary}

\begin{tabular}{|c|c|}
\hline Injury category & Prevention or Remedy \\
\hline Physical Injuries & $\begin{array}{l}\text { 1. Proper lifting techniques: } \\
\text { a. Rolling the body instead of lifting } \\
\text { b. Wearing proper back supports. } \\
\text { 2. Hardwearing, impervious, Non-Slippery floor is essential: } \\
\text { a. Mops the floor to keep surfaces dry } \\
\text { b. Wearing protective shoes } \\
\text { c. Proper ventilation and adequate lighting to keep floor dry. }\end{array}$ \\
\hline Sharp Injury & $\begin{array}{l}\text { 1. Safe handling of needles and sharp instruments: } \\
\text { a. Should not be left lying around the work area } \\
\text { b. Habit of putting scalpels on a firm, stable surface (table) by one prosector and } \\
\text { then picked up by the second } \\
\text { c. Do not hold tissues with the fingers of the non-cutting hand } \\
\text { d. Surgical towels should be placed over the cut edges of the ribs to protect } \\
\text { against a scrape injury } \\
\text { e. Non-pointed (blunt-tipped) scissors should be used wherever possible.[20] } \\
\text { f. Disposal of entire syringe and breaking the needle with needle shredder. } \\
\text { g. Wear cut-resistant gloves (finely woven stainless steel fabric) on the non- } \\
\text { h. Use a thick (3-inch) sponge to stabilize the organ with the non-cutting hand } \\
\text { for organ slices. } \\
\text { Pre autopsy whole body radiography to locate bullet fragments and irregular bone } \\
\text { fragments. }{ }^{41]} \text {. }\end{array}$ \\
\hline Electrical Injury & $\begin{array}{l}\text { 1. } \\
\text { 2. } \\
\text { 2. Cardioverly installed ground fault interrupters (GFI electrical receptors). } \\
\text { 3. } \text { High-quality latex surgical gloves can protect from inadvertent shock. }{ }^{[32]}\end{array}$ \\
\hline $\begin{array}{l}\text { Chemical } \\
\text { Exposure }\end{array}$ & $\begin{array}{l}\text { 1. Adequate ventilation: } \\
\text { a. Air-exhausted and air-conditioned mortuary } \\
\text { b. Negative-pressure isolation room } \\
\text { 2. Wear chemical protective gloves, visors and glasses for protection of face and eye. } \\
\text { 3. Mandatory training for employees exposed to formaldehyde above } 0.1 \mathrm{ppm} .{ }^{[42]}\end{array}$ \\
\hline $\begin{array}{l}\text { Radiation } \\
\text { Exposure }\end{array}$ & $\begin{array}{l}\text { 1. Detail information of the radioisotope (the amount given, and the time of } \\
\text { administration) should be attached to the medical record and death certificate. } \\
\text { 2. Alert the pathologist and the radiation safety officer by the attending physician if } \\
\text { the body contains more than } 5 \mathrm{mCi} \text {. } \\
\text { 3. Wearing radiation-monitoring badges and Standard procedures for X-ray safety } \\
\text { techniques should be followed. } \\
\text { 4. Wearing theProtective rubber gloves can reduce [beta]-radiation very much, but } \\
\text { not the [delta]-radiation from the isotopes.[41] } \\
\text { 5. A team of pathologists may be required to limit individual exposures to } \\
\text { prosectorby performing limited portion of the autopsy. } \\
\text { 6. Female pathologists and assistants of childbearing age should consult } \\
\text { radiotherapist and/or oncologist before commencing the autopsy exposed of } \\
\text { implanted radiation materials. } \\
\text { 7. Autopsy room should be monitored for radioactive contamination and de- } \\
\text { contaminated if necessary. }\end{array}$ \\
\hline
\end{tabular}


TABLE III: Preventive Measures from Contaminants of Infectious Diseases in Mortuary

\begin{tabular}{|c|c|}
\hline $\begin{array}{l}\text { Blood borne } \\
\text { Pathogens }\end{array}$ & $\begin{array}{l}\text { 1. Vaccination against hepatitis B.[43] } \\
\text { 2. Prevent access of Immuno-suppressed or immune deficient individuals } \\
\text { and individuals who have uncovered wounds, weeping skin lesions.[7] } \\
\text { 3. } 10 \% \text { formalin should be introduced into the lungs after appropriate } \\
\text { microbiological specimens have been taken and before the lungs are } \\
\text { examined.[19] } \\
\text { 4. Standard universal precautions are do not apply to faeces, nasal } \\
\text { secretions, sputum, sweat, tears, urine and vomitus unless they contain } \\
\text { visible blood.[8] }\end{array}$ \\
\hline $\begin{array}{l}\text { Agents spread by } \\
\text { aerosols e.g. } \\
\text { Mycobacterium } \\
\text { tuberculosis }\end{array}$ & $\begin{array}{l}\text { 1. Adequate ventilation in the post-mortem room. } \\
\text { 2. Unauthorized entry \& free movement within mortuary should be } \\
\text { prevented.[44] } \\
\text { 3. Bone surfaces should be moistened before sawing to cut down the } \\
\text { dispersal of bone dust. } \\
\text { 4. Plastic cover or a vacuum bone dust collector attach to the vibrating saw. } \\
\text { 5. Immunization with BCG. } \\
\text { 6. In case of tuberculosis infection, surgical masks have proven insufficient, } \\
\text { in such cases, wearing of N-95 respirators should be made mandatory } \\
\text { (High-Efficiency Particulate Air (HEPA) masks.[45] }\end{array}$ \\
\hline $\begin{array}{l}\text { Exotic agents (both } \\
\text { Aerosol transmitted } \\
\text { \& Blood borne) for } \\
\text { which there is no } \\
\text { prophylactic or } \\
\text { post-exposure } \\
\text { treatments }\end{array}$ & $\begin{array}{l}\text { 1. Avoids cuts and punctures. } \\
\text { 2. Protection against tetanus. } \\
\text { 3. All persons in the autopsy room should wear a surgical gown with full } \\
\text { sleeves, surgical cap, goggles and shoe covers }{ }^{[46]} \text { as recommended safety } \\
\text { devices to protect the eyes, skin, and mucous membranes. } \\
\text { 4. All the exposed personnel should have access to appropriate health care } \\
\text { facilities at the earliest. Information should be given to the authorities and } \\
\text { an appropriate medical advice should be sought. } \\
\text { 5. Autopsy personnel should have baseline blood tests / serological status of } \\
\text { HBV and HIV and tuberculin skin test at the time of employment and a } \\
\text { periodic retesting should be undertaken at regular intervals. } \\
\text { Training and education for Staff for safe working environment and } \\
\text { appropriate work practices } \\
\text { 7. Use of labels such as "Danger of infection" on the dead body is } \\
\text { considered appropriate.[47] } \\
\text { Cat. } 1 \text { : BLUE label - Standard precautions are recommended. } \\
\text { Cat. } 2 \text { : YELLOW label - Additional precautions are recommended. } \\
\text { Cat. } 3 \text { : RED label - Stringent infection precautions are recommended. }\end{array}$ \\
\hline
\end{tabular}


TABLE IV: Disinfectants used during Autopsy and their Effectiveness [19]

\begin{tabular}{|c|c|c|c|c|c|}
\hline & Disinfectants & HIV & HBV, C, D & $\mathbf{T b}$ & Drawbacks \\
\hline 1. & $\begin{array}{l}0.5 \text { sodium hypochlorite } \\
\text { solution }\end{array}$ & + & + & - & $\begin{array}{l}\text { Inactivated by organic matter. } \\
\text { Corrode the metallic fittings \& } \\
\text { surfaces. Use for non metallic surface } \\
\text { only. }\end{array}$ \\
\hline 2. & $1 \%$ - 2\% Gluteraldehyde & ++ & ++ & + & $\begin{array}{l}\text { Do not corrode the metal. Ideal for } \\
\text { metallic surfaces. }\end{array}$ \\
\hline 3. & $10 \%$ Formaline & + & + & - & Highly irritant, carcinogenic. \\
\hline 4. & $\begin{array}{l}\text { 1-2\% soluble phenol } \\
\text { derivatives }\end{array}$ & - & - & ++ & $\begin{array}{l}\text { Not inactivated by organic matter. } \\
\text { Do not corrode the metal. }\end{array}$ \\
\hline
\end{tabular}

HIV] - Human Immune-Deficiency Virus, [HBV, C, D] - Hepatitis B, C, D

[Tb] - Tuberculosis, [+] - Sensitive, [-] - Resistant

\section{REFERENCES:}

1. Bonds L, Gaido L, Woods J, Cohn D, Wilson ML. Infectious diseases detected at autopsy among patients at an urban public hospital: 1996-2001. Am J ClinPathol.2003; 119: 866-72.

2. Howard RK. The Death of Common Sense: How Law is Suffocating America. New York, NY: Random House.1994;14:15.

3. Morris SI. Tuberculosis as an Occupational Hazard during Medical Training. American Review of Tuberculosis. 54(1946):140-58.

4. Hartman L, Ellis H, Mohr K. Most Wanted: Facility Issues. Applied Biosafety.2007; 12(4):109111.

5. Ratzan RM, H Schneiderman. AIDS, Autopsies and Abandonment. JAMA.1988; 260: 34663469.

6. DouceronH, L Deforges, R Gherardi, A Sobel, P Chariot. Long-lasting Postmortem Viability of Human Immunodeficiency Virus: A potential risk in Forensic Medicine Practice. Forensic Sci. Int.1993;60: 61-66.

7. Geller SA. The autopsy in Acquired Immunodeficiency Syndrome- How and Why? Arch. Pathol. Lab. Med.1990; 114: 324-329.

8. Ajmani ML. Recommendations for Prevention of HIV Transmission in Health Care Workers Involved in Autopsy and Embalming. J. Forensic Med. Toxicol.1997; 4: 47-50. 
9. Templeton GL, LAIlling, L Young, D Cave, WW Stead, JH Bates. The risk of transmission of M. tuberculosis at the bedside and the autopsy. Ann. Int. Med.1995; 122: 922-5.

10. Ling Li et al. Principles, Practices, and Prospects Biosafety in SARS Autopsies.CID. 2005 September 15;41: $815-23$

11. Johnson MD, Schaffner W, Atkinson J, Pierce MA. Autopsy Risk and Acquisition of HIV Infection. Arch Pathol Lab Med.1997; 121: 64-66.

12. Reichert CM.New Safety Considerations for the AIDS Autopsy. Arch Pathol Lab Med 1992; 116:1109-1110.

13. Nolte KB, Taylor DG, Richmond JY. Biosafety Considerations for Autopsy. Am J Forensic Med Pathol.2002; 23:107-22.

14. Al-Wali W. Biological Safety. The Hospital Autopsy. 2nd edition. Arnold Pub. U.S; 2001:25-36.

15. Lundgren R, Norrman E, AsbergI. Tuberculosis Infection Transmitted at Autopsy. Tubercle.1987; 68:147-50.

16. Newsom SWB, Rowlands C, Matthews J et al. Aerosols in the Mortuary. J ClinPathol.1983; $36: 127-32$.

17. Babb JR, Hall AJ, Marlin R, Ayliffe GA. Bacteriological Sampling of Postmortem Rooms. J Clin Pathol.1989 Jul; 42(7):682-8.

18. Gordon W, Rosa N, Robert, Hockett. The Microbiologic Evaluation and Enumeration of Postmortem Specimens from Human Remains. Encyclopedia of Mortuary Practice. Springfield. Ohio. 453: 1829-32.

19. Harris DM. Biological Safety. In Cotton DWK and Cross SS (eds). Hospital Autopsy. Jaypee Brothers. New Delhi.1993;pp: 14-31.

20. Lucas S.Glove puncture in post mortem room. J Clin Pathol 1992; 45, 548-549

21. World Health Organization: Laboratory biosafety manual, Ed 2, 1993; Geneva, WHO

22. Howard RK. The Death of Common Sense: How Law is Suffocating America. New York, NY: Random House; 1994:14, 15.

23. Richmond JY, McKinney RW, Biosafety in microbiological and biomedical laboratories, ed 4, 1999; Washington, DC, U.S. Department of Health and Human Services

24. Fritzsche FR, Dietel M, Weichert W, Buckendahl AC: Cut-resistant protective gloves in pathology-effective and cost-effective, Virshows Arch 452:313-318, 2008.

25. American Journal of Infectious Diseases Publisher: Science Publications Audience: Professional Format: Magazine/Journal). 
26. Lia Vizzotti, Sergio D.L. Miguel. International Biosafety Guidelines as baseline for multiple risk management in forensics institutions. Proceedings of 55th Annual Biological Safety Conference by American Biological Safety Association. 2012 October 19-24; Morgue Judicial de la Ciudad de Buenos Aires, Republica Argentina.

27. Chui P, Chong P, Chong B, Wagener S. Mobile Biosafety Level-4 Autopsy Facility-An Innovative Solution. Applied Biosafety. 2007;12(4):238-244

28. Wetli CV, Mittleman RE, Rao VJ. An Atlas of Forensic Pathology. Chicago, 1999; IL: ASCP Press: 107-108.)

29. Burton JL. Health and safety at necropsy, J Clin Patho, 2003; 156:254-260.

30. Hutchins KD, Williams AW, Natarajan GA. Neck needle foreign bodies: An added risk for autopsy pathologists, Arch PatholLabMed2001; 125:790-792.

31. O'Briain DS. Patterns of occupational hand injury in pathology.The interaction of blades, needles and the dissector's digits, Arch Pathol Lab Med 1991;115:610-613.

32. Prahlow JA, Guileyardo JM, Barnard JJ. The implantable cardioverter-defibrillator, a potential hazard for autopsy pathologists. Arch Pathol Lab Med. 1997;121:1076-1080

33. Goris JA, Ang S, Navarro C. Exposure to formaldehyde: adverse effects and preventive measures. ASCP Check Sample 1994; ST94-6:34(6).

34. Occupational Safety and Health Administration U.S. Department of Labor. 29 CFR 1910. 1048, Formaldehyde. OSHA website

35. Greenblatt M, Swenberg J, Kang H. Facts about formaldehyde, Pathologist. 1983; 37:648-651.

36. Sterling TD, Weinkan JJ. Reanalysis of lung cancer in a National Cancer Institute study on mortality among industrial workers exposed to formaldehyde. J Occup. Med.1988; 30: 895901

37. Clifford NJ, AS Nies, Organophosphate poisoning from wearing a laundered uniform previously contaminated with parathion. JAMA. 1989; 262: 3035-6.

38. UK Health Departments (1998a) guidance for clinical health care workers: Protection Against Infection with Blood-borne Viruses. London. Department of Health. 1998; 46

39. Claydon SM. The high risk autopsy: recognition and protection. Am J Forensic Med Pathol. 1993; $14: 253-256$.

40. Occupational safety and health administration. Blood borne pathogens. Final standard federal register 1990;46:64175 - 79.

41. Russell MA, Atkinson RD, Klatt EC, Noguchi TT. Safety in bullet recovery procedures: a study of the Black Talon bullet. Am J Forensic Med Pathol. 1995; 16:120-123. 
42. Greenblatt M: Formaldehyde regulations: What you need to know, CAP Today. 1993; 4:3235.

43. Centers for Disease Control. Guidelines for prevention of transmission of human immunodeficiency virus and hepatitis $B$ virus to health-care and public-safety workers. (MMWR) Morb Mortal Wkly Rep. 1989;38:1-37

44. Peters HJ. Morgue and autopsy room design. In: Hutchins GM, ed. Autopsy performance and reporting. Skokie, IL: College of American Pathologists. 1990; 51-4.

45. Center for Disease Control and Prevention. Guidelines for preventing the transmission of Mycobacterium. Tuberculosis in health-care facilities. Morb. Mortal. Week (MMWR). Rep. 1994 October 28; 43(RR13):1-141

46. Pippin DJ, Verderame RA, Weber KK. Efficacy of face masks in preventing inhalation of airborne contaminants. J Oral Maxillofac Surg. 1987; 45:319-23.

47. Precautions for Handling and Disposal of Dead Bodies. Department of Health. Hospital Authority. Food and Environmental Hygiene Department. Kowloon. The 9th edition. 2013. 